\title{
Lysophospholipid (LPA) receptors (version 2019.4) in the IUPHAR/BPS Guide to Pharmacology Database
}

Victoria Blaho ${ }^{1}$, Jerold Chun ${ }^{1}$, Aaron Frantz ${ }^{1}$, Timothy $\mathrm{Hla}^{2}$, Danielle Jones ${ }^{3}$, Deepa Jonnalagadda ${ }^{1}$, Yasuyuki Kihara ${ }^{1}$, Hirotaka Mizuno ${ }^{1}$, Wouter Moolenaar ${ }^{4}$, Chido Mpamhanga ${ }^{5}$, Sarah Spiegel ${ }^{6}$, Valerie Tan $^{1}$ and Yun C. Yung ${ }^{1}$

1. Sanford Burnham Prebys Medical Discovery Institute, USA

2. Cornell University, USA

3. Scripps Research Institute, USA

4. Netherlands Cancer Institute, The Netherlands

5. LifeArc, UK

6. Virginia Commonwealth University, USA

\begin{abstract}
Lysophosphatidic acid (LPA) receptors (nomenclature as agreed by the NC-IUPHAR Subcommittee on Lysophospholipid Receptors [50, 18]) are activated by the endogenous phospholipidLPA. The first receptor, $\mathrm{LPA}_{1}$, was identified as ventricular zone gene-1 (vzg-1) [38], leading to deorphanisation of members of the endothelial differentiation gene (edg) family as other LPA receptors along with sphingosine 1-phosphate (S1P) receptors. Additional LPA receptor GPCRs were later identified. Gene names have been codified as LPAR1, etc. to reflect the receptor function of proteins. The crystal structure of $\mathrm{LPA}_{1}$ was solved and demonstrates extracellular LPA access to the binding pocket, consistent with proposed delivery via autotaxin [12]. These studies have also implicated cross-talk with endocannabinoids via phosphorylated intermediates that can also activate these receptors. The identified receptors can account for most, although not all, LPA-induced phenomena in the literature, indicating that a majority of LPA-dependent phenomena are receptor-mediated. Binding affinities of unlabeled, natural LPA and AEAp to $L P A_{1}$ were measured using backscattering interferometry $\left(\mathrm{pK}_{d}=9\right)[73]$. Binding affinities were 77 -fold lower than than values obtained using radioactivity [111]. Targeted deletion of LPA receptors has clarified signalling pathways and identified physiological and pathophysiological roles. Independent validation by multiple groups has been reported in the peer-reviewed literature for all six LPA receptors described in the tables, including further validation using a distinct read-out via a novel TGF $\alpha$ "shedding" assay [45]. LPA has also been described as an agonist for the transient receptor potential (Trp) ion channel TRPV1 [76] and TRPA1 [53]. LPA was originally proposed to be a ligand for GPCR35, but data show that in fact it is a receptor for CXCL17 [68]. All of these proposed non-GPCR receptor identities require confirmation and are not currently recognized as bona fide LPA receptors.
\end{abstract}

\section{Contents}

This is a citation summary for Lysophospholipid (LPA) receptors in the Guide to Pharmacology database (GtoPdb). It exists purely as an adjunct to the database to facilitate the recognition of citations to and from the database by citation analyzers. Readers will almost certainly want to visit the relevant sections of the database which are given here under database links. 
GtoPdb is an expert-driven guide to pharmacological targets and the substances that act on them. GtoPdb is a reference work which is most usefully represented as an on-line database. As in any publication this work should be appropriately cited, and the papers it cites should also be recognized. This document provides a citation for the relevant parts of the database, and also provides a reference list for the research cited by those parts.

Please note that the database version for the citations given in GtoPdb are to the most recent preceding version in which the family or its subfamilies and targets were substantially changed. The links below are to the current version. If you need to consult the cited version, rather than the most recent version, please contact the GtoPdb curators.

\section{Database links}

Lysophospholipid (LPA) receptors

http://www.guidetopharmacology.org/GRAC/FamilyDisplayForward?familyld=36

Introduction to Lysophospholipid (LPA) receptors

http://www.guidetopharmacology.org/GRAC/FamilyIntroductionForward?familyld=36

Receptors

$\mathrm{LPA}_{1}$ receptor

http://www.guidetopharmacology.org/GRAC/ObjectDisplayForward?objectld=272

$\mathrm{LPA}_{2}$ receptor

http://www.guidetopharmacology.org/GRAC/ObjectDisplayForward?objectld=273

$\mathrm{LPA}_{3}$ receptor

http://www.guidetopharmacology.org/GRAC/ObjectDisplayForward?objectld=274

$\mathrm{LPA}_{4}$ receptor

http://www.guidetopharmacology.org/GRAC/ObjectDisplayForward?objectld=94

$\mathrm{LPA}_{5}$ receptor

http://www.guidetopharmacology.org/GRAC/ObjectDisplayForward?objectld=124

$\mathrm{LPA}_{6}$ receptor

http://www.guidetopharmacology.org/GRAC/ObjectDisplayForward?objectld=163

\section{References}

1. Aikawa S, Kano K, Inoue A and Aoki J. (2017) Proliferation of mouse endometrial stromal cells in culture is highly sensitive to lysophosphatidic acid signaling. Biochem. Biophys. Res. Commun. 484: 202-208 [PMID:28073697]

2. Allard J, Barrón S, Diaz J, Lubetzki C, Zalc B, Schwartz JC and Sokoloff P. (1998) A rat G protein-coupled receptor selectively expressed in myelin-forming cells. Eur. J. Neurosci. 10: 1045-53 [PMID:9753172]

3. Amisten S, Braun OO, Bengtsson A and Erlinge D. (2008) Gene expression profiling for the identification of G-protein coupled receptors in human platelets. Thromb. Res. 122: 47-57 [PMID:17920662]

4. An S, Bleu T, Hallmark OG and Goetzl EJ. (1998) Characterization of a novel subtype of human G proteincoupled receptor for lysophosphatidic acid. J. Biol. Chem. 273: 7906-10 [PMID:9525886]

5. Azeem Z, Jelani M, Naz G, Tariq M, Wasif N, Kamran-Ul-Hassan Naqvi S, Ayub M, Yasinzai M, Amin-UdDin M and Wali A et al.. (2008) Novel mutations in G protein-coupled receptor gene (P2RY5) in families with autosomal recessive hypotrichosis (LAH3). Hum. Genet. 123: 515-9 [PMID:18461368]

6. Azhar A, Tariq M, Baig SM, Dahl N and Klar J. (2012) A novel mutation in lysophosphatidic acid receptor 6 gene in autosomal recessive hypotrichosis and evidence for a founder effect. Eur J Dermatol 22: 464-6 [PMID:22531990]

7. Balogh A, Shimizu Y, Lee SC, Norman DD, Gangwar R, Bavaria M, Moon C, Shukla P, Rao R and Ray R et al.. (2015) The autotaxin-LPA2 GPCR axis is modulated by $\mathrm{Y}$-irradiation and facilitates DNA damage repair. Cell. Signal. 27: 1751-62 [PMID:26027517] 
8. Bandoh K, Aoki J, Hosono H, Kobayashi S, Kobayashi T, Murakami-Murofushi K, Tsujimoto M, Arai H and Inoue K. (1999) Molecular cloning and characterization of a novel human G-protein-coupled receptor, EDG7, for lysophosphatidic acid. J. Biol. Chem. 274: 27776-85 [PMID:10488122]

9. Bandoh K, Aoki J, Taira A, Tsujimoto M, Arai H and Inoue K. (2000) Lysophosphatidic acid (LPA) receptors of the EDG family are differentially activated by LPA species. Structure-activity relationship of cloned LPA receptors. FEBS Lett. 478: 159-65 [PMID:10922489]

10. Beck HP, Kohn T, Rubenstein S, Hedberg C, Schwandner R, Hasslinger K, Dai K, Li C, Liang L and Wesche $\mathrm{H}$ et al.. (2008) Discovery of potent LPA2 (EDG4) antagonists as potential anticancer agents. Bioorg. Med. Chem. Lett. 18: 1037-41 [PMID:18178086]

11. Choi JW, Herr DR, Noguchi K, Yung YC, Lee CW, Mutoh T, Lin ME, Teo ST, Park KE, Mosley AN and Chun J. (2010) LPA receptors: subtypes and biological actions. Annu. Rev. Pharmacol. Toxicol. 50: 157-86 [PMID:20055701]

12. Chrencik JE, Roth CB, Terakado M, Kurata H, Omi R, Kihara Y, Warshaviak D, Nakade S, Asmar-Rovira $\mathrm{G}$ and Mileni M et al.. (2015) Crystal Structure of Antagonist Bound Human Lysophosphatidic Acid Receptor 1. Cell 161: 1633-43 [PMID:26091040]

13. Chun J, Hla T, Lynch KR, Spiegel S and Moolenaar WH. (2010) International Union of Basic and Clinical Pharmacology. LXXVIII. Lysophospholipid receptor nomenclature. Pharmacol. Rev. 62: 579-87 [PMID:21079037]

14. Contos JJ and Chun J. (2000) Genomic characterization of the lysophosphatidic acid receptor gene, $\mathrm{Ip}(\mathrm{A} 2) / \mathrm{Edg} 4$, and identification of a frameshift mutation in a previously characterized cDNA. Genomics 64 : 155-69 [PMID:10729222]

15. Contos JJ and Chun J. (1998) Complete cDNA sequence, genomic structure, and chromosomal localization of the LPA receptor gene, IpA1/vzg-1/Gpcr26. Genomics 51: 364-78 [PMID:9721207]

16. Contos JJ, Fukushima N, Weiner JA, Kaushal D and Chun J. (2000) Requirement for the IpA1 lysophosphatidic acid receptor gene in normal suckling behavior. Proc. Natl. Acad. Sci. U.S.A. 97: 13384-9 [PMID:11087877]

17. Dancs PT, Ruisanchez É, Balogh A, Panta CR, Miklós Z, Nüsing RM, Aoki J, Chun J, Offermanns S and Tigyi $G$ et al.. (2017) $L P A_{1}$ receptor-mediated thromboxane $A_{2}$ release is responsible for lysophosphatidic acid-induced vascular smooth muscle contraction. FASEB J. 31: 1547-1555 [PMID:28069828]

18. Davenport AP, Alexander SP, Sharman JL, Pawson AJ, Benson HE, Monaghan AE, Liew WC, Mpamhanga CP, Bonner TI and Neubig RR et al.. (2013) International Union of Basic and Clinical Pharmacology. LXXXVIII. G protein-coupled receptor list: recommendations for new pairings with cognate ligands. Pharmacol. Rev. 65: 967-86 [PMID:23686350]

19. Diao H, Aplin JD, Xiao S, Chun J, Li Z, Chen S and Ye X. (2011) Altered spatiotemporal expression of collagen types I, III, IV, and VI in Lpar3-deficient peri-implantation mouse uterus. Biol. Reprod. 84: 255-65 [PMID:20864640]

20. Diez-Roux G, Banfi S, Sultan M, Geffers L, Anand S, Rozado D, Magen A, Canidio E, Pagani M and Peluso I et al.. (2011) A high-resolution anatomical atlas of the transcriptome in the mouse embryoPLoS Biol. 9: e1000582 [PMID:21267068]

21. Dubin AE, Bahnson T, Weiner JA, Fukushima N and Chun J. (1999) Lysophosphatidic acid stimulates neurotransmitter-like conductance changes that precede GABA and L-glutamate in early, presumptive cortical neuroblasts. J. Neurosci. 19: 1371-81 [PMID:9952414]

22. Dubin AE, Herr DR and Chun J. (2010) Diversity of lysophosphatidic acid receptor-mediated intracellular calcium signaling in early cortical neurogenesis. J. Neurosci. 30: 7300-9 [PMID:20505096]

23. Durgam GG, Virag T, Walker MD, Tsukahara R, Yasuda S, Liliom K, van Meeteren LA, Moolenaar WH, Wilke N and Siess W et al.. (2005) Synthesis, structure-activity relationships, and biological evaluation of fatty alcohol phosphates as lysophosphatidic acid receptor ligands, activators of PPARgamma, and inhibitors of autotaxin. J. Med. Chem. 48: 4919-30 [PMID:16033271]

24. Estivill-Torrús G, Llebrez-Zayas P, Matas-Rico E, Santín L, Pedraza C, De Diego I, Del Arco I, FernándezLlebrez P, Chun J and De Fonseca FR. (2008) Absence of LPA1 signaling results in defective cortical 
development. Cereb. Cortex 18: 938-50 [PMID:17656621]

25. Fells JI, Tsukahara R, Fujiwara Y, Liu J, Perygin DH, Osborne DA, Tigyi G and Parrill AL. (2008) Identification of non-lipid LPA3 antagonists by virtual screening. Bioorg. Med. Chem. 16: 6207-17 [PMID:18467108]

26. Fells JI, Tsukahara R, Liu J, Tigyi G and Parrill AL. (2009) Structure-based drug design identifies novel LPA3 antagonists. Bioorg. Med. Chem. 17: 7457-64 [PMID:19800804]

27. Fischer DJ, Liliom K, Guo Z, Nusser N, Virág T, Murakami-Murofushi K, Kobayashi S, Erickson JR, Sun G and Miller DD et al.. (1998) Naturally occurring analogs of lysophosphatidic acid elicit different cellular responses through selective activation of multiple receptor subtypes. Mol. Pharmacol. 54: 979-88 [PMID:9855625]

28. Fischer DJ, Nusser N, Virag T, Yokoyama K, Wang Da, Baker DL, Bautista D, Parrill AL and Tigyi G. (2001) Short-chain phosphatidates are subtype-selective antagonists of lysophosphatidic acid receptors. Mol. Pharmacol. 60: 776-84 [PMID:11562440]

29. Fukushima N, Ishii I, Habara Y, Allen CB and Chun J. (2002) Dual regulation of actin rearrangement through lysophosphatidic acid receptor in neuroblast cell lines: actin depolymerization by $\mathrm{Ca}(2+)$-alphaactinin and polymerization by rho. Mol. Biol. Cell 13: 2692-705 [PMID:12181339]

30. Fukushima N, Kimura $Y$ and Chun J. (1998) A single receptor encoded by vzg-1/lpA1/edg-2 couples to $G$ proteins and mediates multiple cellular responses to lysophosphatidic acid. Proc. Natl. Acad. Sci. U.S.A. 95: 6151-6 [PMID:9600933]

31. Fukushima N, Shano S, Moriyama R and Chun J. (2007) Lysophosphatidic acid stimulates neuronal differentiation of cortical neuroblasts through the LPA1-G(i/o) pathway. Neurochem. Int. 50: 302-7 [PMID:17056154]

32. Fukushima N, Weiner JA and Chun J. (2000) Lysophosphatidic acid (LPA) is a novel extracellular regulator of cortical neuroblast morphology. Dev. Biol. 228: 6-18 [PMID:11087622]

33. Fukushima N, Weiner JA, Kaushal D, Contos JJ, Rehen SK, Kingsbury MA, Kim KY and Chun J. (2002) Lysophosphatidic acid influences the morphology and motility of young, postmitotic cortical neurons. Mol. Cell. Neurosci. 20: 271-82 [PMID:12093159]

34. Hama K, Aoki J, Inoue A, Endo T, Amano T, Motoki R, Kanai M, Ye X, Chun J and Matsuki Net al.. (2007) Embryo spacing and implantation timing are differentially regulated by LPA3-mediated lysophosphatidic acid signaling in mice. Biol. Reprod. 77: 954-9 [PMID:17823089]

35. Hasegawa Y, Erickson JR, Goddard GJ, Yu S, Liu S, Cheng KW, Eder A, Bandoh K, Aoki J and Jarosz R et al.. (2003) Identification of a phosphothionate analogue of lysophosphatidic acid (LPA) as a selective agonist of the LPA3 receptor. J. Biol. Chem. 278: 11962-9 [PMID:12554733]

36. Hata E, Sasaki N, Takeda A, Tohya K, Umemoto E, Akahoshi N, Ishii S, Bando K, Abe T and Kano Ket al.. (2016) Lysophosphatidic acid receptors LPA4 and LPA6 differentially promote lymphocyte transmigration across high endothelial venules in lymph nodes. Int. Immunol. 28: 283-92 [PMID:26714589]

37. Heasley BH, Jarosz R, Lynch KR and Macdonald TL. (2004) Initial structure-activity relationships of lysophosphatidic acid receptor antagonists: discovery of a high-affinity LPA1/LPA3 receptor antagonist. Bioorg. Med. Chem. Lett. 14: 2735-40 [PMID:15125924]

38. Hecht JH, Weiner JA, Post SR and Chun J. (1996) Ventricular zone gene-1 (vzg-1) encodes a lysophosphatidic acid receptor expressed in neurogenic regions of the developing cerebral cortex. J. Cell Biol. 135: 1071-83 [PMID:8922387]

39. Heise CE, Santos WL, Schreihofer AM, Heasley BH, Mukhin YV, Macdonald TL and Lynch KR. (2001) Activity of 2-substituted lysophosphatidic acid (LPA) analogs at LPA receptors: discovery of a LPA1/LPA3 receptor antagonist. Mol. Pharmacol. 60: 1173-80 [PMID:11723223]

40. Herr KJ, Herr DR, Lee CW, Noguchi K and Chun J. (2011) Stereotyped fetal brain disorganization is induced by hypoxia and requires lysophosphatidic acid receptor 1 (LPA1) signaling. Proc. Natl. Acad. Sci. U.S.A. 108: 15444-9 [PMID:21878565]

41. Horev L, Saad-Edin B, Ingber A and Zlotogorski A. (2010) A novel deletion mutation in P2RY5/LPA(6) gene cause autosomal recessive woolly hair with hypotrichosis. J Eur Acad Dermatol Venereo/24: 858-9 
[PMID:20015179]

42. Igarashi H, Akahoshi N, Ohto-Nakanishi T, Yasuda D and Ishii S. (2015) The lysophosphatidic acid receptor LPA4 regulates hematopoiesis-supporting activity of bone marrow stromal cells. Sci Rep 5: 11410 [PMID:26090649]

43. Im DS. (2010) Pharmacological tools for lysophospholipid GPCRs: development of agonists and antagonists for LPA and S1P receptors. Acta Pharmacol. Sin. 31: 1213-22 [PMID:20729877]

44. Im DS, Heise CE, Harding MA, George SR, O'Dowd BF, Theodorescu D and Lynch KR. (2000) Molecular cloning and characterization of a lysophosphatidic acid receptor, Edg-7, expressed in prostate. Mol. Pharmacol. 57: 753-9 [PMID:10727522]

45. Inoue A, Ishiguro J, Kitamura $H$, Arima N, Okutani M, Shuto A, Higashiyama S, Ohwada T, Arai $H$ and Makide $\mathrm{K}$ et al.. (2012) TGF $\alpha$ shedding assay: an accurate and versatile method for detecting GPCR activation. Nat. Methods 9: 1021-9 [PMID:22983457]

46. Ishii I, Contos JJ, Fukushima $N$ and Chun J. (2000) Functional comparisons of the lysophosphatidic acid receptors, LP(A1)/VZG-1/EDG-2, LP(A2)/EDG-4, and LP(A3)/EDG-7 in neuronal cell lines using a retrovirus expression system. Mol. Pharmacol. 58: 895-902 [PMID:11040035]

47. Jongsma M, Matas-Rico E, Rzadkowski A, Jalink K and Moolenaar WH. (2011) LPA is a chemorepellent for B16 melanoma cells: action through the cAMP-elevating LPA5 receptor. PLoS ONE 6: e29260 [PMID:22195035]

48. Kano K, Arima N, Ohgami M and Aoki J. (2008) LPA and its analogs-attractive tools for elucidation of LPA biology and drug development. Curr. Med. Chem. 15: 2122-31 [PMID:18781939]

49. Kawamoto $Y$, Seo R, Murai N, Hiyama H and Oka H. (2018) Identification of potent lysophosphatidic acid receptor 5 (LPA5) antagonists as potential analgesic agents. Bioorg. Med. Chem. 26: 257-265 [PMID:29208511]

50. Kihara Y, Maceyka M, Spiegel S and Chun J. (2014) Lysophospholipid receptor nomenclature review: IUPHAR Review 8. Br. J. Pharmacol. 171: 3575-94 [PMID:24602016]

51. Kingsbury MA, Rehen SK, Contos JJ, Higgins CM and Chun J. (2003) Non-proliferative effects of lysophosphatidic acid enhance cortical growth and folding. Nat. Neurosci. 6: 1292-9 [PMID:14625558]

52. Kiss GN, Fells JI, Gupte R, Lee SC, Liu J, Nusser N, Lim KG, Ray RM, Lin FT and Parrill ALet al.. (2012) Virtual screening for LPA2-specific agonists identifies a nonlipid compound with antiapoptotic actions. Mol. Pharmacol. 82: 1162-73 [PMID:22968304]

53. Kittaka H, Uchida K, Fukuta N and Tominaga M. (2017) Lysophosphatidic acid-induced itch is mediated by signalling of $\mathrm{LPA}_{5}$ receptor, phospholipase D and TRPA1/TRPV1.J. Physiol. (Lond.) 595: 2681-2698 [PMID:28176353]

54. Kotarsky K, Boketoft A, Bristulf J, Nilsson NE, Norberg A, Hansson S, Owman C, Sillard R, Leeb-Lundberg LM and Olde B. (2006) Lysophosphatidic acid binds to and activates GPR92, a G protein-coupled receptor highly expressed in gastrointestinal lymphocytes. J. Pharmacol. Exp. Ther. 318: 619-28 [PMID:16651401]

55. Kozian DH, Evers A, Florian P, Wonerow P, Joho $S$ and Nazare M. (2012) Selective non-lipid modulator of LPA5 activity in human platelets. Bioorg. Med. Chem. Lett. 22: 5239-43 [PMID:22801643]

56. Kritikou E, van Puijvelde GH, van der Heijden T, van Santbrink PJ, Swart M, Schaftenaar FH, Kröner MJ, Kuiper $J$ and Bot I. (2016) Inhibition of lysophosphatidic acid receptors 1 and 3 attenuates atherosclerosis development in LDL-receptor deficient mice. Sci Rep 6: 37585 [PMID:27883026]

57. Lee CW, Rivera R, Dubin AE and Chun J. (2007) LPA(4)/GPR23 is a lysophosphatidic acid (LPA) receptor

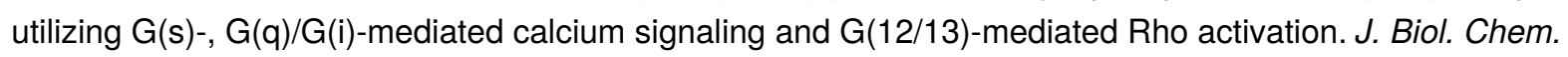
282: 4310-7 [PMID:17166850]

58. Lee CW, Rivera R, Gardell S, Dubin AE and Chun J. (2006) GPR92 as a new G12/13- and Gq-coupled lysophosphatidic acid receptor that increases CAMP, LPA5. J. Biol. Chem. 281: 23589-97 [PMID:16774927]

59. Lee M, Choi S, Halldén G, Yo SJ, Schichnes D and Aponte GW. (2009) P2Y5 is a G(alpha)i, $\mathrm{G}$ (alpha)12/13 $\mathrm{G}$ protein-coupled receptor activated by lysophosphatidic acid that reduces intestinal cell adhesion. Am. J. Physiol. Gastrointest. Liver Physiol. 297: G641-54 [PMID:19679818] 
60. Lee Z, Cheng CT, Zhang H, Subler MA, Wu J, Mukherjee A, Windle JJ, Chen CK and Fang X. (2008) Role of LPA4/p2y9/GPR23 in negative regulation of cell motility. Mol. Biol. Cell 19: 5435-45 [PMID:18843048]

61. Li Q, Schachter JB, Harden TK and Nicholas RA. (1997) The 6H1 orphan receptor, claimed to be the p2y5 receptor, does not mediate nucleotide-promoted second messenger responses. Biochem. Biophys. Res. Commun. 236: 455-60 [PMID:9240460]

62. Liliom K, Tsukahara T, Tsukahara R, Zelman-Femiak M, Swiezewska E and Tigyi G. (2006) Farnesyl phosphates are endogenous ligands of lysophosphatidic acid receptors: inhibition of LPA GPCR and activation of PPARs. Biochim. Biophys. Acta 1761: 1506-14 [PMID:17092771]

63. Lin ME, Rivera RR and Chun J. (2012) Targeted deletion of LPA5 identifies novel roles for lysophosphatidic acid signaling in development of neuropathic pain. J. Biol. Chem. 287: 17608-17 [PMID:22461625]

64. Lin S, Yeruva S, He P, Singh AK, Zhang H, Chen M, Lamprecht G, de Jonge HR, Tse M, Donowitz M, Hogema BM, Chun J, Seidler U and Yun CC. (2010) Lysophosphatidic acid stimulates the intestinal brush border $\mathrm{Na}(+) / \mathrm{H}(+)$ exchanger 3 and fluid absorption via LPA(5) and NHERF2. Gastroenterology 138: 64958 [PMID:19800338]

65. Lu Y, Wang Z, Li CM, Chen J, Dalton JT, Li W and Miller DD. (2010) Synthesis, in vitro structure-activity relationship, and in vivo studies of 2-arylthiazolidine-4-carboxylic acid amides as anticancer agents. Bioorg. Med. Chem. 18: 477-95 [PMID:20056548]

66. Lundequist A and Boyce JA. (2011) LPA5 is abundantly expressed by human mast cells and important for lysophosphatidic acid induced MIP-1 $\beta$ release. PLoS ONE 6: e18192 [PMID:21464938]

67. Mahmoudi H, Tug E, Parlak AH, Atasoy HI, Ludwig M, Polat M, Pasternack SM and Betz RC. (2012) Identification of an Alu-mediated 12.2-kb deletion of the complete LPAR6 (P2RY5) gene in a Turkish family with hypotrichosis and woolly hair. Exp. Dermatol. 21: 469-71 [PMID:22621192]

68. Maravillas-Montero JL, Burkhardt AM, Hevezi PA, Carnevale CD, Smit MJ and Zlotnik A. (2015) Cutting edge: GPR35/CXCR8 is the receptor of the mucosal chemokine CXCL17. J. Immunol. 194: 29-33 [PMID:25411203]

69. Matas-Rico E, García-Diaz B, Llebrez-Zayas P, López-Barroso D, Santín L, Pedraza C, Smith-Fernández A, Fernández-Llebrez P, Tellez T and Redondo M et al.. (2008) Deletion of lysophosphatidic acid receptor LPA1 reduces neurogenesis in the mouse dentate gyrus. Mol. Cell. Neurosci. 39: $342-55$ [PMID:18708146]

70. McGiffert C, Contos JJ, Friedman B and Chun J. (2002) Embryonic brain expression analysis of lysophospholipid receptor genes suggests roles for $\mathrm{s} 1 \mathrm{p}(1)$ in neurogenesis and $\mathrm{s} 1 \mathrm{p}(1-3)$ in angiogenesis. FEBS Lett. 531: 103-8 [PMID:12401212]

71. Mclntyre TM, Pontsler AV, Silva AR, St Hilaire A, Xu Y, Hinshaw JC, Zimmerman GA, Hama K, Aoki J and Arai $\mathrm{H}$ et al.. (2003) Identification of an intracellular receptor for lysophosphatidic acid (LPA): LPA is a transcellular PPARgamma agonist. Proc. Natl. Acad. Sci. U.S.A. 100: 131-6 [PMID:12502787]

72. Mirendil H, Thomas EA, De Loera C, Okada K, Inomata $Y$ and Chun J. (2015) LPA signaling initiates schizophrenia-like brain and behavioral changes in a mouse model of prenatal brain hemorrhage. Transl Psychiatry 5: e541 [PMID:25849980]

73. Mizuno H, Kihara Y, Kussrow A, Chen A, Ray M, Rivera R, Bornhop DJ and Chun J. (2019) Lysophospholipid $\mathrm{G}$ protein-coupled receptor binding parameters as determined by backscattering interferometry. J. Lipid Res. 60: 212-217 [PMID:30463988]

74. Mukherjee A, Ma Y, Yuan F, Gong Y, Fang Z, Mohamed EM, Berrios E, Shao H and Fang X. (2015) Lysophosphatidic Acid Up-Regulates Hexokinase II and Glycolysis to Promote Proliferation of Ovarian Cancer Cells. Neoplasia 17: 723-34 [PMID:26476080]

75. Nakamura M and Tokura Y. (2009) Congenital woolly hair without P2RY5 mutation.Dermatoendocrinol 1: 58-9 [PMID:20046591]

76. Nieto-Posadas A, Picazo-Juárez G, Llorente I, Jara-Oseguera A, Morales-Lázaro S, Escalante-Alcalde D, Islas LD and Rosenbaum T. (2012) Lysophosphatidic acid directly activates TRPV1 through a C-terminal binding site. Nat. Chem. Biol. 8: 78-85 [PMID:22101604]

77. Noguchi K, Ishii S and Shimizu T. (2003) Identification of p2y9/GPR23 as a novel G protein-coupled 
receptor for lysophosphatidic acid, structurally distant from the Edg family. J. Biol. Chem. 278: 25600-6 [PMID:12724320]

78. Ochiai S, Furuta D, Sugita K, Taniura H and Fujita N. (2013) GPR87 mediates lysophosphatidic acidinduced colony dispersal in A431 cells. Eur. J. Pharmacol. 715: 15-20 [PMID:23831392]

79. Oh DY, Yoon JM, Moon MJ, Hwang JI, Choe H, Lee JY, Kim JI, Kim S, Rhim H, O'Dell DK, Walker JM, Na HS, Lee MG, Kwon HB, Kim K and Seong JY. (2008) Identification of farnesyl pyrophosphate and Narachidonylglycine as endogenous ligands for GPR92. J. Biol. Chem. 283: 21054-64 [PMID:18499677]

80. Ohashi T and Yamamoto T. (2015) Antifibrotic effect of lysophosphatidic acid receptors LPA1 and LPA3 antagonist on experimental murine scleroderma induced by bleomycin. Exp. Dermatol. 24: 698-702 [PMID:25959255]

81. Ohta H, Sato K, Murata N, Damirin A, Malchinkhuu E, Kon J, Kimura T, Tobo M, Yamazaki Y, Watanabe T, Yagi M, Sato M, Suzuki R, Murooka H, Sakai T, Nishitoba T, Im DS, Nochi H, Tamoto K, Tomura H and Okajima F. (2003) Ki16425, a subtype-selective antagonist for EDG-family lysophosphatidic acid receptors. Mol. Pharmacol. 64: 994-1005 [PMID:14500756]

82. Ohuchi H, Hamada A, Matsuda H, Takagi A, Tanaka M, Aoki J, Arai H and Noji S. (2008) Expression patterns of the lysophospholipid receptor genes during mouse early development. Dev. Dyn. 237: 3280-94 [PMID:18924241]

83. Okusa MD, Ye H, Huang L, Sigismund L, Macdonald T and Lynch KR. (2003) Selective blockade of lysophosphatidic acid LPA3 receptors reduces murine renal ischemia-reperfusion injury. Am. J. Physiol. Renal Physiol. 285: F565-74 [PMID:12770838]

84. Pasternack SM, Murugusundram S, Eigelshoven S, Müller M, Kruse R, Lehmann P and Betz RC. (2009) Novel mutations in the P2RY5 gene in one Turkish and two Indian patients presenting with hypotrichosis and woolly hair. Arch. Dermatol. Res. 301: 621-4 [PMID:19529952]

85. Pasternack SM, von Kügelgen I, Aboud KA, Lee YA, Rüschendorf F, Voss K, Hillmer AM, Molderings GJ, Franz T, Ramirez A, Nürnberg P, Nöthen MM and Betz RC. (2008) G protein-coupled receptor P2Y5 and its ligand LPA are involved in maintenance of human hair growth. Nat. Genet. 40: 329-34 [PMID:18297070]

86. Pasternack SM, von Kügelgen I, Müller M, Oji V, Traupe H, Sprecher E, Nöthen MM, Janecke AR and Betz RC. (2009) In vitro analysis of LIPH mutations causing hypotrichosis simplex: evidence confirming the role of lipase $\mathrm{H}$ and lysophosphatidic acid in hair growth. J. Invest. Dermatol. 129: 2772-6 [PMID:19536142]

87. Pedraza C, Sánchez-López J, Castilla-Ortega E, Rosell-Valle C, Zambrana-Infantes E, García-Fernández M, Rodriguez de Fonseca F, Chun J, Santín LJ and Estivill-Torrús G. (2014) Fear extinction and acute stress reactivity reveal a role of LPA(1) receptor in regulating emotional-like behaviors. Brain Struct Funct 219: 1659-72 [PMID:23775489]

88. Petukhova L, Sousa Jr EC, Martinez-Mir A, Vitebsky A, Dos Santos LG, Shapiro L, Haynes C, Gordon D, Shimomura $Y$ and Christiano AM. (2008) Genome-wide linkage analysis of an autosomal recessive hypotrichosis identifies a novel P2RY5 mutation. Genomics 92: 273-8 [PMID:18692127]

89. Plastira I, Bernhart E, Goeritzer M, Reicher H, Kumble VB, Kogelnik N, Wintersperger A, Hammer A, Schlager S and Jandl K et al.. (2016) 1-Oleyl-lysophosphatidic acid (LPA) promotes polarization of BV-2 and primary murine microglia towards an M1-like phenotype. J Neuroinflammation 13: 205 [PMID:27565558]

90. Qian L, Xu Y, Simper T, Jiang G, Aoki J, Umezu-Goto M, Arai H, Yu S, Mills GB and Tsukahara Ret al.. (2006) Phosphorothioate analogues of alkyl lysophosphatidic acid as LPA3 receptor-selective agonists. ChemMedChem 1: 376-83 [PMID:16892372]

91. Santos WL, Heasley BH, Jarosz R, Carter KM, Lynch KR and Macdonald TL. (2004) Synthesis and biological evaluation of phosphonic and thiophosphoric acid derivatives of lysophosphatidic acid. Bioorg. Med. Chem. Lett. 14: 3473-6 [PMID:15177455]

92. Sattikar A, Dowling MR and Rosethorne EM. (2017) Endogenous lysophosphatidic acid (LPA1) receptor agonists demonstrate ligand bias between calcium and ERK signalling pathways in human lung fibroblasts. Br. J. Pharmacol. 174: 227-237 [PMID:27864940] 
93. Schmitz K, Brunkhorst R, de Bruin N, Mayer CA, Häussler A, Ferreiros N, Schiffmann S, Parnham MJ, Tunaru S and Chun J et al.. (2017) Dysregulation of lysophosphatidic acids in multiple sclerosis and autoimmune encephalomyelitis. Acta Neuropathol Commun 5: 42 [PMID:28578681]

94. Shimomura Y, Garzon MC, Kristal L, Shapiro L and Christiano AM. (2009) Autosomal recessive woolly hair with hypotrichosis caused by a novel homozygous mutation in the P2RY5 gene. Exp. Dermatol. 18: 218-21 [PMID:18803659]

95. Shimomura Y, Wajid M, Ishii Y, Shapiro L, Petukhova L, Gordon D and Christiano AM. (2008) Disruption of P2RY5, an orphan G protein-coupled receptor, underlies autosomal recessive woolly hair. Nat. Genet. 40: 335-9 [PMID:18297072]

96. Simon MF, Daviaud D, Pradère JP, Grès S, Guigné C, Wabitsch M, Chun J, Valet $P$ and Saulnier-Blache JS. (2005) Lysophosphatidic acid inhibits adipocyte differentiation via lysophosphatidic acid 1 receptordependent down-regulation of peroxisome proliferator-activated receptor gamma2. J. Biol. Chem. 280: 14656-62 [PMID:15710620]

97. Southern C, Cook JM, Neetoo-Isseljee Z, Taylor DL, Kettleborough CA, Merritt A, Bassoni DL, Raab WJ, Quinn E and Wehrman TS et al.. (2013) Screening $\beta$-Arrestin Recruitment for the Identification of Natural Ligands for Orphan G-Protein-Coupled Receptors. J Biomol Screen 18: 599-609 [PMID:23396314]

98. Swaney JS, Chapman C, Correa LD, Stebbins KJ, Broadhead AR, Bain G, Santini AM, Darlington J, King CD and Baccei CS et al.. (2011) Pharmacokinetic and pharmacodynamic characterization of an oral lysophosphatidic acid type 1 receptor-selective antagonist. J. Pharmacol. Exp. Ther. 336: 693-700 [PMID:21159750]

99. Swaney JS, Chapman C, Correa LD, Stebbins KJ, Bundey RA, Prodanovich PC, Fagan P, Baccei CS, Santini AM and Hutchinson JH et al.. (2010) A novel, orally active LPA(1) receptor antagonist inhibits lung fibrosis in the mouse bleomycin model. Br. J. Pharmacol. 160: 1699-713 [PMID:20649573]

100. Taniguchi R, Inoue A, Sayama M, Uwamizu A, Yamashita K, Hirata K, Yoshida M, Tanaka Y, Kato HE and Nakada-Nakura $Y$ et al.. (2017) Structural insights into ligand recognition by the lysophosphatidic acid receptor $\mathrm{LPA}_{6}$. Nature 548: 356-360 [PMID:28792932]

101. Tariq M, Ayub M, Jelani M, Basit S, Naz G, Wasif N, Raza SI, Naveed AK, ullah Khan S and Azeem Zet al.. (2009) Mutations in the P2RY5 gene underlie autosomal recessive hypotrichosis in 13 Pakistani families. Br. J. Dermatol. 160: 1006-10 [PMID:19292720]

102. Terakado M, Suzuki H, Hashimura K, Tanaka M, Ueda H, Kohno H, Fujimoto T, Saga H, Nakade S and Habashita $\mathrm{H}$ et al.. (2016) Discovery of ONO-7300243 from a Novel Class of Lysophosphatidic Acid Receptor 1 Antagonists: From Hit to Lead. ACS Med Chem Lett 7: 913-918 [PMID:27774128]

103. Virag T, Elrod DB, Liliom K, Sardar VM, Parrill AL, Yokoyama K, Durgam G, Deng W, Miller DD and Tigyi G. (2003) Fatty alcohol phosphates are subtype-selective agonists and antagonists of lysophosphatidic acid receptors. Mol. Pharmacol. 63: 1032-42 [PMID:12695531]

104. von Kügelgen I. (2006) Pharmacological profiles of cloned mammalian P2Y-receptor subtypes. Pharmacol. Ther. 110: 415-32 [PMID:16257449]

105. Webb TE, Kaplan MG and Barnard EA. (1996) Identification of $6 \mathrm{H} 1$ as a P2Y purinoceptor: P2Y5. Biochem. Biophys. Res. Commun. 219: 105-10 [PMID:8619790]

106. Weiner JA and Chun J. (1999) Schwann cell survival mediated by the signaling phospholipid lysophosphatidic acid. Proc. Natl. Acad. Sci. U.S.A. 96: 5233-8 [PMID:10220449]

107. Weiner JA, Fukushima N, Contos JJ, Scherer SS and Chun J. (2001) Regulation of Schwann cell morphology and adhesion by receptor-mediated lysophosphatidic acid signaling. J. Neurosci. 21: 7069-78 [PMID:11549717]

108. Williams JR, Khandoga AL, Goyal P, Fells JI, Perygin DH, Siess W, Parrill AL, Tigyi G and Fujiwara Y. (2009) Unique ligand selectivity of the GPR92/LPA5 lysophosphatidate receptor indicates role in human platelet activation. J. Biol. Chem. 284: 17304-19 [PMID:19366702]

109. Xu Y, Aoki J, Shimizu K, Umezu-Goto M, Hama K, Takanezawa Y, Yu S, Mills GB, Arai H and Qian Let al.. (2005) Structure-activity relationships of fluorinated lysophosphatidic acid analogues.J. Med. Chem. 48: 3319-27 [PMID:15857137] 
110. Yanagida K, Ishii S, Hamano F, Noguchi K and Shimizu T. (2007) LPA4/p2y9/GPR23 mediates rhodependent morphological changes in a rat neuronal cell line. J. Biol. Chem. 282: 5814-24 [PMID:17172642]

111. Yanagida K, Masago K, Nakanishi H, Kihara Y, Hamano F, Tajima Y, Taguchi R, Shimizu T and Ishii S. (2009) Identification and characterization of a novel lysophosphatidic acid receptor, p2y5/LPA6. J. Biol. Chem. 284: 17731-41 [PMID:19386608]

112. Yang AH, Ishii I and Chun J. (2002) In vivo roles of lysophospholipid receptors revealed by gene targeting studies in mice. Biochim. Biophys. Acta 1582: 197-203 [PMID:12069829]

113. Ye X, Hama K, Contos JJ, Anliker B, Inoue A, Skinner MK, Suzuki H, Amano T, Kennedy G and Arai łt al.. (2005) LPA3-mediated lysophosphatidic acid signalling in embryo implantation and spacing.Nature 435: 104-8 [PMID:15875025]

114. Ye X, Skinner MK, Kennedy G and Chun J. (2008) Age-dependent loss of sperm production in mice via impaired lysophosphatidic acid signaling. Biol. Reprod. 79: 328-36 [PMID:18448840]

115. Yukiura H, Kano K, Kise R, Inoue A and Aoki J. (2015) LPP3 localizes LPA6 signalling to non-contact sites in endothelial cells. J. Cell. Sci. 128: 3871-7 [PMID:26345369]

116. Yung YC, Mutoh T, Lin ME, Noguchi K, Rivera RR, Choi JW, Kingsbury MA and Chun J. (2011) Lysophosphatidic acid signaling may initiate fetal hydrocephalus. Sci Trans/ Med3: 99ra87 [PMID:21900594]

117. Yung YC, Stoddard NC and Chun J. (2014) LPA receptor signaling: pharmacology, physiology, and pathophysiology. J. Lipid Res. 55: 1192-1214 [PMID:24643338]

118. Zhang H, Xu X, Gajewiak J, Tsukahara R, Fujiwara Y, Liu J, Fells Jl, Perygin D, Parrill AL and Tigyi Get al.. (2009) Dual activity lysophosphatidic acid receptor pan-antagonist/autotaxin inhibitor reduces breast cancer cell migration in vitro and causes tumor regression in vivo. Cancer Res. 69: 5441-9 [PMID:19509223] 